\title{
Hva er evidensbaserte råd?
}

\author{
Det kan være gode grunner til å være frustrert over norsk helsepolitikk, men hvor går egentlig grensen \\ mellom politikk og fag? Evidens er et hyppig brukt ord, men man hører sjelden noen definere hva de mener \\ med uttrykket.
}

Norske gynekologer er frustrert over at deres råd om overtidig svangerskap og testing for humant papillomvirus (HPV) ikke er tatt til følge av Helse- og omsorgsdepartementet (1). «Anbefalinger og retningslinjer bør være kunnskapsbasert,» skriver Øian og medarbeidere i en kommentarartikkel i Tidsskriftet. De bør være evidensbaserte, for å bruke deres egen overskrift. Spørsmålet blir da hva som er gyldig kunnskap eller hva man mener med evidens. Evidens er et hyppig brukt ord, men man hører sjelden noen definere hva de mener med uttrykket. Cochrane-bevegelsens definisjon er upresis og bygd på sirkulær argumentasjon (2).

To motstridende oppfatninger kan begge gjøre krav på å være evidensbaserte. Cochrane-forkjemperen Peter Gøtzche har i en årrekke hevdet at screening for brystkreft ikke reduserer dødeligheten (3). Hans motstandere mener at det er deres standpunkt som er evidensbasert (4). Faglig uenighet blir altså ikke borte med evidensbasert medisin.

Evidensbasert medisin handler i stor grad om valg av diagnostiske tester eller behandling. Optimale valg kan oftest ikke baseres på klinisk erfaring. Det er nettopp derfor evidensbasert medisin har hatt så mye vind i seilene. Optimale valg må baseres på forskning der man tar i bruk statistikk og epidemiologi. Avdøde professor Knut Westlund pleide å si at bare $5 \%$ av leger med doktorgrad kan tolke en p-verdi korrekt. Det passer godt med min egen erfaring. I møte med økonomer, statsvitere, statistikere og psykologer har jeg ofte fått høre at de er overrasket over hvor liten metodekompetanse leger har. Leger har selvsagt en unik kompetanse i utøvelse av klinisk praksis, men de fleste har etter min erfaring moderat kompetanse når det gjelder å vurdere om behandling A har lavere dødelighet enn behandling B eller om test A har lavere sensitivitet enn test B. Det er ikke overraskende om helseforvaltningens ansatte med annen fagbakgrunn enn medisin vurderer råd fra legene med en smule skepsis.

\section{Fordelingsspørsmål og politikk}

Norsk helsepolitikk er preget av ønsket om rettferdig fordeling. Politikerne ønsker at folk med lav inntekt skal ha like god helse som de mer bemidlede, og at folk i utkantstrøk skal ha like god helsetjeneste som folk i byene. Slike fordelingshensyn kan medføre at politikerne velger behandling A fordi A gir mer lik fordeling av helse eller helsetjenester, selv om behandling B har lavere dødelighet.

Fordelingsspørsmål er altså et politisk anliggende der leger ikke har noen spesiell kompetanse. Vi kan godt være frustrert over at hensynet til for eksempel arbeidsplasser påvirker helsepolitikken, men det er legitimt og i pakt med demokratiet at politikere tar slike hensyn.

\section{Verdivurderinger}

Valg av diagnostikk og behandling dreier seg ikke bare om objektivt målbare størrelser som for eksempel dødelighet, blodtrykk eller tilstedeværelse av HPV-virus, det handler også om pasienters preferanser og verdivurderinger. Det er legitimt at en

\section{«Gode råd fra leger kan være viktige i utformingen av norsk helsepolitikk»}

kreftpasient velger kjemoterapi A fremfor terapi B selv om B gir signifikant lavere dødelighet. Bivirkninger og risiko for umiddelbar død kan gjøre kjemoterapi A til det optimale valg (5).

Fremtredende samfunnsmedisinere har argumentert for at pasientpreferanser bør bygges inn i faglige retningslinjer (6).

Et godt eksempel på dette kan være screening for livmorhalskreft. Det tas mer enn 350000 celleprøver per år i Norge, mer enn 30000 kvinner innkalles til etterkontroll og 3000 av disse har alvorlige celleforandringer (CIN2+) og blir konisert (7). Hvor mange av disse ville ha utviklet invasiv kreft uten konisering? Følgende beregninger kan gi en indikasjon. Omtrent halvparten av de ca. 300 tilfellene av invasiv kreft som påvises i løpet av ett år, har oppstått hos de $20 \%$ av norske kvinner som ikke har tatt celleprøve (7). Samme insidens hos de $80 \%$ av kvinnene som deltar screeningen, utgjør 600 tilfeller. Dette estimatet kan være for høyt, fordi kvinner som ikke møter til screening, gjerne har høyere sykdomsrisiko enn gjennomsnittet. Modellsimuleringer med norske data tyder på at antall krefttil- feller uten screening ville ha vært ca. 500 (8). Antall forebygde krefttilfeller er med disse tall i størrelsesorden 200-450. Det er altså hevet over enhver tvil at en betydelig andel av de 3000 som făr utført konisering, aldri ville ha utviklet invasiv $\operatorname{kreft}(9,10)$. Histologiske forandringer (CIN2+) er med andre ord et usikkert surrogatendepunkt.

Tallene reiser flere spørsmål. Hvordan skal man informere kvinner om at sannsynligheten for falskt positiv prøve er nesten $10 \%$ - dvs. rundt 30000 av 350000 prøver per år? Når og på hvilken måte skal man informere om at anslagsvis fem av seks kvinner som får utført konisering, ikke ville ha utviklet invasiv kreft? Når og på hvilken måte skal man informere om bivirkninger, slik som senaborter og for tidlig fødsel i senere svangerskap, etter konisering (11)?

Screening for livmorhalskreft handler om å avveie risiko for livmorhalskreft mot risiko for unødvendige bekymringer og risiko for bivirkninger etter konisering. Kvinner gjør trolig ulike avveininger, og noen kan velge å ta en liten kreftrisiko for å unngå falskt positive prøver eller redusert fertilitet. Dette er en type valg vi alle gjør fra tid til annen. Vi utsetter oss for dødsrisiko ved å kjøre bil eller gå over gaten. Vi spiser iblant usunn mat. Vi kan ikke a priori anta at alle kvinner vil velge screening dersom de er godt informert om alle konsekvenser.

Leger har gode forutsetninger for å opparbeide kompetanse på verdsetting av helsetilstander, sannsynlig effekt av behandling og måling av preferanser. I praksis synes likevel legers interesse for slike temaer å være liten - bedømt ut i fra diskusjoner i offentlige fora eller medisinske publikasjoner. I fravær av verdivurderinger kan ikke legene vente at deres helsepolitiske råd skal bli tatt til følge.

Jeg er ikke er imot screening for livmorhalskreft. Tvert imot er det god grunn til å tro at slik screening både er effektivt og kostnadseffektivt (8). Screeningprogrammet må likevel ta hensyn til den enkelte kvinnes verdivurderinger.

\section{Valg av HPV-test}

Øian og medarbeidere mener at arbeidet med retningslinjer for bruk av HPV-tester i sekundærscreening for livmorhalskreft ble «overstyrt politisk» (1). Striden har stått om en norskutviklet RNA-test. Denne testen er ikke spesielt godt dokumentert (12), men det betyr ikke nødvendigvis at andre tester er å foretrekke. Valg av tester vil avhenge 
av blant annet hvordan man avveier hensynet til sensitivitet og spesifisitet. Det har ikke vært gjort noen kvantitativ analyse av hva de ulike tester betyr for antall sant positive, falskt positive, falskt negative og sant negative. Det er ikke gitt at den testen som oppdager flest forstadier (har høyest sensitivitet), er å foretrekke. Valg av screeningtester må blant annet bygges på kvinners verdsetting av de ulike utfallene. Så vidt jeg vet har ingen offentlig myndighet i Norge gjort analyser der pasientpreferanser er tatt hensyn til, eller beregnet antall falskt positive testresultater med ulike tester.

Helse- og omsorgsdepartementet har fjernet refusjon for den omstridte RNAtesten, visstnok på basis av en rapport fra Kreftregisteret (13). I denne rapporten har man mest vektlagt sensitivitet av de ulike testene og sier lite om spesifisitet og konsekvensene for kvinner som avgir falskt positive tester. Rapporten er bygd på surrogatendepunkter (bl.a. forekomsten av CIN2+) fra rutinedata med sammenlikning av kvinner som har fått tatt ulike typer HPVtester. Oppfølgingstiden var begrenset. Det fantes ingen kontrollgruppe med histologisk prøve fra HPV-negative kvinner. Dette kan selvsagt ikke gjøres i en registerbasert studie, men medfører usikkerhet i tolkingen av resultatene. Refusjonsreglene ble altså endret på basis av en rapport med store metodeproblemer og uten grundig høring i fagmiljøene.

Alle som det siste året har fulgt den opphetede debatten om valg av HPV-tester, vil ha lagt merke til at det finnes to grupper forskere: De som sverger til RNA-tester og de som sverger til DNA-tester. Da er det ikke lett for Helse- og omsorgsdepartementet å vite hvem man skal tro på. Jeg har til gode å se fyllestgjørende dokumentasjon for at DNA-tester er best (14). Det er tankevekkende at så mange leger er opptatt av testvalg, mens interessen er så liten for andre tiltak, for eksempel tiltak for å øke fremmøtet til screening.

Etter min vurdering er HPV-saken et eksempel på at politisk styring var og er nødvendig. Helse- og omsorgsdepartementet har måttet treffe avgjørelser på bakgrunn av motstridende «evidens», manglende kunnskap om verdsetting og manglende analyser av konsekvenser av de ulike testvalg. Man kan undre seg over hvor representative rådgivningsgruppene har vært når rådene fra departementets underliggende etater alle har gått i én retning.

\section{Gode råd}

Gode råd fra leger kan være viktige i utformingen av norsk helsepolitikk. Spørsmålet er hva som karakteriserer gode råd, og hva legenes spesielle kompetanse består i. Legene har en unik kompetanse på utøvelsen av klinisk medisin, men det er oftest ikke det som er det springende punkt i helsepolitikken. Oftere er det spørsmål om effekt av behandling eller nytten av diagnostiske tester. Denne typen vurderinger krever ikke bare klinisk erfaring, men også kompetanse i epidemiologi og verdsetting av helsetilstander. Her kunne legene hatt stor kompetanse, men i praksis har få leger vist interesse for feltet.

\section{«Ved fordelings- spørsmål og politiske vurderinger er legen uten spesiell kompe-}

\section{tanse»}

Ved fordelingsspørsmål og politiske vurderinger er legen uten spesiell kompetanse. Jeg tror legenes rolle som rådgivere i helsepolitikken kunne bli mer effektiv og mindre frustrerende dersom legene foretok et klart skille mellom de ulike typer kompetanse og heller satte inn kreftene der de har genuin kompetanse.

\section{Ivar Sønbø Kristiansen}

i.s.kristiansen@medisin.uio.no

Avdeling for helseledelse og helseøkonomi Universitetet i Oslo

Ivar Sønbø Kristiansen (f. 1947) er professor ved Avdeling for helseledelse og helseøkonomi, Universitetet i Oslo, og spesialist i samfunnsmedisin. Han driver forskning innen helseøkonomi og risikokommunikasjon. Han er medlem av en gruppe som utreder bruk av HPV-testing i primærscreening for livmorhalskreft. Forfatter har fylt ut ICMJE-skjemaet og oppgir følgende interessekonflikter: Han har mottatt honorar fra RNA-testprodusenten Norchip for foredrag om epidemiologi og testegenskaper i 2007 og 2009.
Litteratur

1. Øian P, Iversen OE, Hordnes K et al. Mer evidens og mindre politikk, takk! Tidsskr Nor Legeforen 2011; 131: 2346

2. Kristiansen IS, Mooney G. Evidence-based medicine: method, collaboration, movement or crusade? I: Kristiansen IS, Mooney G, red. Evidencebased medicine - in its place. London: Routledge, 2006: 1-19.

3. Gøtzsche PC. Time to stop mammography screening? CMAJ 2011; 183: 1957-8.

4. Tonelli M, Gorber SC, Joffres M et al. Recommendations on screening for breast cancer in averagerisk women aged 40-74 years. CMAJ 2011; 183 : 1991-2001.

5. McNeil BJ, Weichselbaum R, Pauker SG. Fallacy of the five-year survival in lung cancer. $\mathrm{N}$ Engl J Med 1978; 299: 1397-401.

6. Krahn M, Naglie G. The next step in guideline development: incorporating patient preferences. JAMA 2008; 300: 436-8

7. Johansen BK, Skare GB, Haldorsen T et al. Årsrapport 2008. Masseundersøkelser mot livmorhalskreft. Oslo: Kreftregisteret, 2009

8. Burger EA, Ortendahl JD, Sy S et al. Cost-effectiveness of primary human papillomavirus (HPV) testing in Norway: implications for current screening and vaccination practices loral presentation Society of Medical Decision Making Chicago 22-26 Oct 2011). Med Decis Making 2012; 32. Akseptert for publisering.

9. McCredie MR, Sharples KJ, Paul C et al. Natural history of cervical neoplasia and risk of invasive cancer in women with cervical intraepithelial neoplasia 3: a retrospective cohort study. Lancet Oncol 2008; 9: 425-34

10. Ostör AG. Natural history of cervical intraepithelial neoplasia: a critical review. Int J Gynecol Pathol 1993; 12: 186-92

11. Albrechtsen S, Rasmussen S, Thoresen $\mathrm{S}$ et al. Pregnancy outcome in women before and after cervical conisation: population based cohort study. BMJ 2008; 337 (sep18 1): a1343.

12. Burger EA, Kornør H, Klemp M et al. HPV mRNA tests for the detection of cervical intraepithelial neoplasia: a systematic review. Gynecol Oncol 2011; 120: 430-8.

13. Haldorsen T, Skare GB, Bjørge T. Sekundærscreening med HPV-tester i Masseundersøkelsen mot Livmorhalskreft. Oslo: Kreftregisteret, 2011.

14. Kristiansen IS. HPV-testing: tid for nøktern analyse. Dagens Medisin 24.3.2011.

Mottatt 29.2. 2012 og godkjent 8.3. 2012. Medisinsk redaktør Petter Gjersvik. 